\title{
Studies on Lignin
}

\section{IV. * Investigation on the Nitrobenzene Oxidation Products of Lignin from Different Woods by Paper Partition Chromatography}

\author{
BENGTLEOPOLD and INGA-LILLMALMSTRÖM
}

Organisk-kemiska Institutionen, Kungl. Tekniska Högskolan, Stockholm, Sweden

Tn

n general, there are characteristic differences between lignin from plants belonging to different botanical groups, although there is relative uniformity within each group. Thus, the Mäule ${ }^{1}$ colour test is, with some exception, negative with gymnosperms but positive with dicotyledons and monocotyledons $2,3$.

In 1934 Holmberg published an important paper on the study of lignins extracted from over fifty plant species, using thioglycolic acid as the extraction agent. He clearly demonstrated that the carbon contents of lignins from gymnosperms are generally $3-5 \%$ higher than those of lignins from angiosperms, and at the same time the latter lignins often show a higher methoxyl content.

Of the more recent investigations in this field, one of the most important, dealing with the oxidation products from numerous species of gymnosperms, dicotyledons and monocotyledons, was carried out by Hibbert et al. ${ }^{5}$. These workers used the nitrobenzene oxidation technique introduced by Freudenberg et al. ${ }^{6}$ and found that with a few exceptions, the gymnosperms yielded vanillin as the only aldehydic oxidation product, while the angiosperms yielded both vanillin and syringaldehyde, usually in the ratio $1: 3$. In addition, some of the monocotyledons yielded considerable amounts of $p$-hydroxybenzaldehyde ?. They also showed that woods which gave a positive Mäule test, always yielded syringaldehyde ${ }^{8}$.

The main differences in the structure of lignin from plants of different botanical groups should therefore consist in variations of the amounts of guaia-

* Part III. Acta Chem. Scand. 6 (1952) 38. 
Table 1. Nitrobenzene oxidation of gymnosperm lignin.

\begin{tabular}{|c|c|c|c|c|c|c|c|c|c|c|}
\hline & \multirow{2}{*}{ 峞 } & \multirow{2}{*}{ 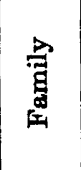 } & \multirow{2}{*}{ Species } & \multirow{2}{*}{$\underset{\%}{\mathrm{OCH}_{2}}$} & \multirow{2}{*}{$\underset{\%}{\text { Klason }} \underset{\%}{\text { lignin }}$} & \multicolumn{2}{|c|}{$\begin{array}{c}\text { Total alde- } \\
\text { hydes based on }\end{array}$} & \multirow{2}{*}{$\mid \begin{array}{c}\text { p-Hydr- } \\
\text { oxy- } \\
\text { benz- } \\
\text { aidehyde } \\
\% *\end{array}$} & \multirow{2}{*}{$=\begin{array}{l}\text { Syring- } \\
\text { alde- } \\
\text { hyde } \\
\%\end{array}$} & \multirow{2}{*}{ Remarks } \\
\hline & & & & & & $\underset{\%}{\mathrm{OCH}_{3}}$ & $\underset{\%}{\operatorname{lignin}}$ & & & \\
\hline & ఫે & 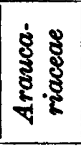 & $\begin{array}{l}\text { Araucaria araucana (Mol.) } \\
\text { Koch } \\
\text { Agathis alba (Rumph.) } \\
\text { Warburg }\end{array}$ & $\begin{array}{l}4.92 \\
5.70\end{array}$ & $\begin{array}{r}27.6 \\
- \\
\end{array}$ & $\begin{array}{l}31.1 \\
32.5\end{array}$ & - & $\begin{array}{l}+ \\
++\end{array}$ & $\begin{array}{l}- \\
+\end{array}$ & \\
\hline & 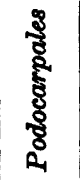 & 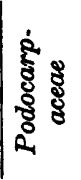 & $\begin{array}{l}\text { Dacrydium cupressinum Sol. } \\
\text { Podocarpus spicatus } \mathrm{R} \text {. Br. } \\
\text { Podocarpus Totara D. Don. } \\
\text { Phyllocladus romboidalis } \\
\text { Rich. }\end{array}$ & $\begin{array}{l}5.20 \\
5.68 \\
6.33 \\
5.64\end{array}$ & $\begin{array}{l}- \\
- \\
35.6 \\
32.3\end{array}$ & $\begin{array}{l}31.6 \\
31.1 \\
31.0 \\
31.1\end{array}$ & $\begin{array}{l}- \\
- \\
27.1 \\
26.6\end{array}$ & $\begin{array}{l}(+) \\
++ \\
+ \\
++\end{array}$ & $\begin{array}{l}++ \\
- \\
3.0 \\
+\end{array}$ & \\
\hline : & 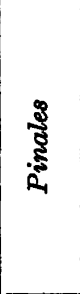 & 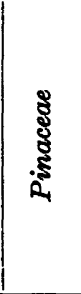 & $\begin{array}{l}\text { Pseudotsuga taxifolia } \\
\quad \text { (Poir.) Britt. } \\
\text { Tsuga heterophylla(R.) Sarg. } \\
\text { Tsuga canadensis (L.) Carr. } \\
\text { Picea abies (L.) Karst. } \\
\text { Larix sibirica Ledeb. } \\
\text { Cedrus Deodara (Roxb.) Loud } \\
\text { Pinus sylvestris L. }\end{array}$ & $\begin{array}{l}4.47 \\
5.05 \\
5.30 \\
4.92 \\
4.66 \\
5.50 \\
4.71\end{array}$ & $\begin{array}{l}26.0 \\
- \\
31.2 \\
27.5 \\
- \\
31.1 \\
26.9\end{array}$ & $\begin{array}{l}31.9 \\
31.2 \\
32.0 \\
31.6 \\
32.4 \\
30.5 \\
31.7\end{array}$ & $\begin{array}{l}26.9 \\
- \\
26.6 \\
28.0 \\
- \\
26.4 \\
27.3\end{array}$ & $\begin{array}{c}t+ \\
(+) \\
3.5 \\
++t \\
++ \\
+++ \\
+++\end{array}$ & $\begin{array}{c}++ \\
- \\
++ \\
+ \\
++ \\
++ \\
+\end{array}$ & $\begin{array}{l}\text { Syringic acid detected } \\
\text { No syringic acid } \\
\text { Syringic acid detected } \\
\text { Possibly also } p \text {-hydr. } \\
\text { oxy benzoic acid } \\
\text { Syringic acid detected }\end{array}$ \\
\hline כ & 3 & 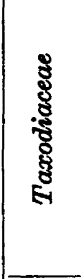 & $\begin{array}{l}\text { Sciadopitys verticillata } \\
\text { (Thunb.) Sieb. et Zucc. } \\
\text { Sequoiadendron giganteum } \\
\text { (Lindl.) Buch } \\
\text { Taxodium distichum Rich. } \\
\text { Cryptomeria japonica } \\
\text { (L. fil) Don. } \\
\text { Athrotaxis selaginoides Don. }\end{array}$ & $\begin{array}{r}5.74 \\
6.10 \\
6.20 \\
5.20 \\
5.78 \\
\end{array}$ & $\begin{array}{l}35.4 \\
37.0 \\
- \\
- \\
\end{array}$ & \begin{tabular}{|l|r|}
32.3 & \\
31.6 & \\
& 32.6 \\
32.2 & \\
\end{tabular} & $\begin{array}{l}27.3 \\
26.0 \\
- \\
-\end{array}$ & $\begin{array}{l}3.5 \\
2.0 \\
2.5 \\
2.5\end{array}$ & $\begin{array}{l}(+) \\
(+) \\
(+) \\
+ \\
++\end{array}$ & \\
\hline & 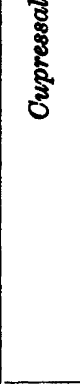 & 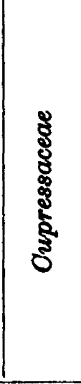 & $\begin{array}{l}\text { Tetraclinis articulata } \\
\text { (Wahl) Mast. } \\
\text { Widdringtonia juniperoides } \\
\text { (L.) Endl. } \\
\text { Thuja plicata D. Don } \\
\text { Libocedrus chilensis } \\
\text { (D. Don) Endl. } \\
\text { Cupressus Macnabiana Murr } \\
\text { Chamaeyparis nootkatensis } \\
\text { (Lamb.) Spach } \\
\text { Juniperus communis L. }\end{array}$ & $\begin{array}{l}\mathbf{5 . 4 4} \\
6.09 \\
5.55 \\
5.55 \\
\\
5.30 \\
5.33\end{array}$ & $\begin{array}{l}- \\
33.2 \\
31.2 \\
- \\
- \\
30.0\end{array}$ & $\begin{array}{l}31.0 \\
30.3 \\
\\
30.0 \\
32.0 \\
\\
32.4 \\
31.4\end{array}$ & $\begin{array}{l}- \\
27.4 \\
26.2 \\
- \\
- \\
27.4\end{array}$ & $\begin{array}{c}+ \\
(+) \\
+ \\
3.5 \\
3.0 \\
+ \\
2.5\end{array}$ & $\begin{array}{l}\sim 50 \\
- \\
(+) \\
(+) \\
(+) \\
+ \\
-\end{array}$ & No syringic acid \\
\hline & केष & 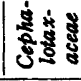 & $\begin{array}{l}\text { Cephalotaxus drupacea } \\
\text { Sieb. et Zucc. }\end{array}$ & 6.13 & 36.1 & 25.0 & 21.4 & + & - & \\
\hline 8 & स्ष & हुँ & Taxus baccata $\mathrm{L}$. & 5.69 & 32.5 & 27.4 & 23.6 & 3.5 & - & \\
\hline
\end{tabular}

* - no spot

$(+)$ identification uncertain

$+\quad 0.5 \%$ or less of tot. aldeh.

$++0.5-1.0 \%$-" -

$+++1.0-2.0 \% \quad-"-$

In general, amounts corresponding to $0.1-0.2 \%$ of total aldehydes give spots which are barely visible

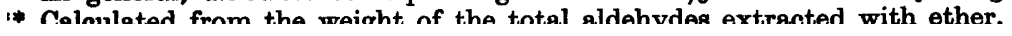


cyl, syringyl and $p$-hydroxyphenyl elements present, thus giving rise to the variations in carbon and methoxyl content.

The methods used by Hibbert to isolate and separate the different aldehydes made it very difficult to detect small amounts of for example syringaldehyde, in mixture with a large amount of vanillin. Therefore, when one of the present authors succeeded in identifying small amounts of $p$-hydroxybenzaldehyde and syringaldehyde among the nitrobenzene oxidation products from spruce wood (Part III), using chromatographic methods, it seemed to be of interest to extend this study to some other species of wood.

In an investigation of a large group of plants such as the Conifers, the coverage must necessarily be very incomplete, but we have tried to select species available in this department and which at the same time formed a representative cross-section of the whole group.

The oxidations and isolation of the aldehyde mixtures (in a few cases also the acid fractions) and the paper chromatographic analyses were carried out as described in Part III. The aldehydes were estimated by the bisulphite titration method described previously ${ }^{9}$, giving values which were generally $3-4 \%$ lower than the corresponding weights of the aldehyde mixtures obtained by ether extraction. The total yields of aldehydes were calculated (as vanillin) on the basis of the methoxyl content and, in many cases, also of the lignin content of the extracted dry wood.

Table 1 lists the results obtained, with the different species. The yields of $p$-hydroxybenzaldehyde and syringaldehyde indicated by + signs or figures are of course very approximative, since they have been determined visually by comparison of the intensities of the spots on the paper chromatograms, with spots obtained from standard solutions (cf. experimental part).

In addition, the oxidation products from three common hardwoods were studied (Table 2).

Table 2. Nitrobenzene oxidation of hardwood lignin.

\begin{tabular}{|l|c|c|c|c|c|}
\hline \multicolumn{1}{|c|}{ Species } & $\begin{array}{c}\mathrm{OCH}_{3} \\
\%\end{array}$ & $\begin{array}{c}\text { Klason } \\
\text { lignin } \\
\%\end{array}$ & $\begin{array}{c}\text { Total alde- } \\
\text { hydes based } \\
\text { on lignin } \\
\%\end{array}$ & $\begin{array}{c}\text { p-Hydroxy- } \\
\text { benzalde- } \\
\text { hyde } \\
\%\end{array}$ & $\begin{array}{c}\text { Syring- } \\
\text { aldehyde } \\
\%\end{array}$ \\
\hline Acer platanoides & 6.15 & 24.2 & 44.6 & $(+)$ & $\sim 75$ \\
Betula papyrifera & 5.40 & 20.0 & 47.0 & $(+)$ & $\sim 75$ \\
Populus sp. & 5.60 & 25.0 & 40.0 & + & $\sim 75$ \\
\hline
\end{tabular}


The results listed in Table 1 indicate that most Conifers yield $p$-hydroxybenzaldehyde but that the occurrence of syringaldehyde is not nearly so general. The highest yields of $p$-hydroxybenzaldehyde are given by members of the families Taxodiaceae and Pinaceae, although some representatives of the family Cupressaceae also give significant amounts.

Syringaldehyde seems to occur most frequently in the Pinaceae. In the Podocarpaceae, the genus Podocarpus is of especial interest as Hibbert showed that some species give high yields of syringaldehyde while others (Podocarpus neriifolius and $P$. acutifolium) give none. The latter two species together with $P$. macrophyllus $v$. maki (presence of syringaldehyde uncertain) would of course have been of interest for the present investigation, but they were unfortunately not available. The study of two other Podocarpus species, however, tends to give support to the view that the composition of lignin from Podocarpus varies considerably, the various species giving syringaldehyde in yields varying from 0 to $50 \%$ of the total aldehydes.

In the Cupressaceae, the yield of syringaldehyde in general is low or nil with the peculiar exception of Tetraclinis articulata which Hibbert found gave an aldehyde mixture containing about $45 \%$ of syringaldehyde.

The most surprising inconsistency in Table 1 is the great difference between Tsuga canadensis and Tsuga heterophylla, the latter giving very little or no $p$-hydroxybenzaldehyde and syringaldehyde and thus being perhaps an exceptional member of the family Pinaceae.

Before drawing any definite conclusions, however, knowledge must be gained about the individual variations within each species by investigating a large number of wood samples. This, however, is entirely outside the scope of the present investigation. (In the case of Picea abies, three samples were studied, and gave almost identical results.)

The few acid fractions investigated always contained syringic acid if the corresponding aldehyde fraction contained syringaldehyde, but no $p$-hydroxybenzoic acid could be detected except possibly in the case of Picea abies (cf. Part III).

The total yields of aldehydes were very uniform. With three exceptions they varied between 30.0 and $32.6 \%$ (average $31.6 \%$ ) based on the methoxyl content, and between 26.0 and $28.0 \%$ (average $27.0 \%$ ) based on the lignin content of the wood. This variation is insignificant as three different samples of the same species (Picea abies) gave yields of 32.1, 31.6 and $30.8 \%$ (28.0, 28.0 and $27.0 \%$ ) respectively.

Cephalotaxus drupacea and Taxus baccata gave yields of aldehydes lower than the average and it is interesting to note that Cephalotaxus has been considered to be related to Taxus, although the modern trend seems to be to 
place Taxus outside the Conifer group. The high yield of aldehydes from Tetraclinis articulata is, of course, due to the large amount of syringaldehyde present.

It may be mentioned that the total yields of aldehydes reported by Hibbert were much lower than those reported here, and in addition, varied considerably from species to species. This discrepancy is probably due to the fact that Hibbert did not employ optimal oxidation conditions. He states that the time of reaction may be reduced from 3 hours to 2 hours at $160^{\circ}$ when only small amounts of material are oxidized, but this seems to be quite improbable and is, in fact, not in agreement with recent experimental findings ${ }^{10}$.

\section{EXPERIMENTAL}

In each experiment powdered, air-dried wood $(3-5 \mathrm{~g}$ previously extracted with benzene-ethanol (1:1)), was oxidized by the method described in Part III. Only the bisulphitesoluble fractions of the oxidation products were investigated, except in five cases (see Table 1), when in addition the acid fractions were recovered and examined. (Cf. Part III.)

After removal of the sulphur dioxide, cooling and filtering, an aliquot of the bisulphite extract was titrated to determine the total aldehyde content ${ }^{9}$, and the remainder of the solution was extracted with ether to recover the aldehydes. The ether solutions were dried over sodium sulphate, the ether evaporated, and the crystalline residue analysed by means of paper chromatography as described in Part III.

The semi-quantitative estimation of the relative amounts of $p$-hydroxybenzaldehyde and syringaldehyde was carried out in the following way:

$50 \mathrm{Mg}$ of the sample to be investigated were dissolved in ethanol $(1 \mathrm{ml})$ and part of this solution was sucked into a capillary pipet to a predetermined height. The solution was then applied to the paper dropwise (10 drops), with drying between each drop. The same procedure with the same pipet was used for the standard solutions, containing amounts of $p$-hydroxybenzaldehyde and syringaldehyde corresponding to $0.2,0.5,0.7$, 1.0, 1.5, 2.0, 3.0, 5.0 and $25 \%$ of the total aldehydes. Chromatograms were run as described in Part III.

By comparing visually the spots from the unknown samples with those from the standard solutions, a comparatively good estimate of the relative amounts could be obtained, especially if the concentrations were not too high.

\section{SUMMARY}

The nitrobenzene oxidation products from the wood of 27 Conifers and 3 hardwoods have been studied by means of paper partition chromatography.

The wood from almost all coniferous genera gives small and varying amounts of $p$-hydroxybenzaldehyde. The families Taxodiaceae and Pinaceae give comparatively high and uniform yields. Many Conifers, belonging mainly to the family Pinaceae, give small amounts of syringaldehyde. The results 
obtained with Podocarpus species and Tetraclinis articulata confirm the earlier results of Hibbert.

The hardwoods investigated gave, in addition to vanillin and syringaldehyde, only very little or no $p$-hydroxybenzaldehyde.

On the whole, the total yields of aldehydes showed very small deviations from the average within the whole class Coniferae.

The authors wish to express their thanks to Statens Tekniska Forskningsrdid for financial support.

\section{REFERENCES}

1. Mäule, C. Beitr. wiss. Botan. 4 (1900) 166.

2. Crocker, E. C. Ind. Eng. Chem. 13 (1921) 625.

3. Sharma, P. D. J. Forestry 20 (1922) 476.

4. Holmberg, B. Ing. Vetenskaps Akad. Handl. No. 131 (1934).

5. Creighton, R. H. J., Gibbs, R. D., and Hibbert, H. J. Am. Chem. Soc. 66 (1944) 32.

6. Freudenberg, K., Lautsch, W., and Engler, K. Ber. 73 (1940) 167.

7. Creighton, R. H. J., and Hibbert, H. J. Am. Chem. Soc. 66 (1944) 37.

8. Cf. Campbell, W. G., McGowan, J. C., and Bryant, S. A. Biochem. J. 32 (1938) 2138.

9. Leopold, B. Acta Chem. Scand. 4 (1950) 1535.

10. Leopold, B. Svensk Kem. Tid. 64 (1952) 1. 